\title{
Boguslawa Drelich-Skulska
}

Wroclaw University of Economics and Business

e-mail: boguslawa.drelich-skulska@ue.wroc.pl

ORCID: 0000-0003-0233-1850

\author{
Anna H. Jankowiak \\ Wroclaw University of Economics and Business \\ e-mail: anna.jankowiak@ue.wroc.pl
}

ORCID: 0000-0001-6208-9387

\section{CLUSTERS AS AN ELEMENT OF REGIONAL SPECIALISATION BASED ON THE EXAMPLE OF LOWER SILESIA}

\section{KLASTRY JAKO ELEMENT SPECJALIZACJI REGIONALNEJ NA PRZYKLADZIE DOLNEGO ŚLĄSKA}

DOI: $10.15611 / \mathrm{br} .2019 .1 .03$

JEL Classification: F15, L52, O25

\begin{abstract}
Summary: Strategy Europe 2020 is intended to support smart specialisation, i.e. the innovative development of individual regions which benefit from what constitutes their specific and unique features. Regions have to indicate their strong points, and focus their activities on those areas of science and innovativeness which are complimentary to a given region's resources and ultimately will create or strengthen its comparative advantages. The aim of this article is to present the concept itself, as well as the theoretical principles of smart specialisation in a regional dimension. In turn, they will become the basis for examining the role and the importance of clusters in the development of the regional specialisation of Lower Silesia. At the same time, the authors studied the possibilities of creating new clusters and their relevance for mapping out future areas of specialisation of the region, corresponding with the objectives of Strategy Europe 2020.
\end{abstract}

Keywords: regional specialisation, smart specialisation, clusters, Lower Silesia. 
Streszczenie: Strategia Europa 2020 zakłada wspieranie inteligentnej specjalizacji, tzn. innowacyjnego rozwoju poszczególnych regionów, które czerpią korzyści z tego, co stanowi o ich specyfice i wyjątkowości. Zgodnie z tą koncepcją regiony muszą wykazać swoje mocne i słabe strony i koncentrować działania na tych dziedzinach nauki i obszarach innowacyjności, które będą komplementarne względem zasobów danego regionu, a docelowo będą się przyczyniały do tworzenia lub wzmacniania przewag komparatywnych regionu. Celem artykułu jest ukazanie koncepcji oraz przedstawienie założeń teoretycznych inteligentnej specjalizacji w wymiarze regionalnym, które stanie się osnową do oceny roli i znaczenia klastrów w rozwijaniu specjalizacji regionalnej na Dolnym Śląsku. Jednocześnie zbadano możliwości kreowania nowych klastrów i ich istotności w wytyczaniu przyszłych specjalizacji badanego regionu, wpisujących się w założenia strategii Europa 2020.

Słowa kluczowe: specjalizacja regionalna, smart specialisation, klastry, Dolny Śląsk.

\section{Regional specialisation - theoretical approach}

Smart specialisation is a new concept in the regional policy of the European Union, and a tool used to determine and build a position of a region or country within a knowledge-based economy. Strategy Europe 2020 is intended to support smart specialisation, i.e. the innovative development of individual regions which benefit from what constitutes their specific and unique features. According to that concept, regions have to indicate their strong and weak points, and focus their activities on those domains of science and areas of innovativeness which will be complimentary to the resources of the region in question, and ultimately will contribute to the creation of its comparative advantages.

The aim of this article is to present the concept itself as well as the theoretical principles of smart specialisation in a regional dimension, which in turn will become the basis for the study of the role and importance of clusters in developing regional specialization in Lower Silesia. The authors also explored the possibilities of creating new clusters and their relevance for mapping out the future specialisations of the studied region, corresponding with the goals of Strategy Europe 2020. The research objective was carried out using the methods of analysis and literature review, by analysing documents (reports of international organizations, strategic national and regional documentation, and the official announcements made by the local government administration), analysis and a logical construction.

The term specialisation comes from the Latin word 'specialis' meaning 'particular, special' and in everyday language means attaining skills, expertise in a particular domain.

Among the mechanisms of regional specialisation are the following streams of its interpretation:

- regional specialisation in the aspect of competitiveness of companies and their localisation,

- regional specialisation accompanying the processes of growth in innovativeness and regional competitiveness, 
- regional specialisation determining the processes of territorial development [Ochojski et al. 2016].

Currently the most widely-used term in research on matters concerning regional development is 'smart specialisation'. The analysis of EU documents allows to define it as setting the research and development, technological and innovation priorities of a region or country, which:

- use the strong points, competitive advantage and improvement potential of a region/country,

- have been determined as a result of engaging a wide spectrum of stakeholders, and at the same time encouraging innovation and experiments,

- are supported by policy and investment (mostly in the private sector) aimed at ensuring a knowledge-based development,

- are the element of a smart development strategy, based on facts and involving the appropriate systems of monitoring and evaluation [National/Regional Innovation...; Nazarko 2014, pp. 247-262].

Yet it should be noted, which is also confirmed by its authors, that the concept does not have any solid theoretical basis and the many contradictions and dilemmas it contains so far have not been resolved, or at least subjected to a wider analysis [Foray, David, Hall 2011].

The creators of the concept of smart specialisation indicate the four main principles on which it is based (the four Cs), namely: (Tough) Choices and Critical Mass; Competitive Advantage; Connectivity and Clusters; Collaborative Leadership. They also point out that the creation of a smart specialization should not be reduced to a merely bureaucratic procedure or expert advice commissioned from external consultants [Foray et al. 2012]. The choice of a specialization should be selective, based on the best-developed resources and also the unique resources of the region. It should be adapted to the specificity of the given region, with the inclusion of its existing assets and capabilities, and the localization in the environment. By observing those, the possibility will arise to create and implement a strategy to compete with other regions.

Strategy Europe 2020 proposes a new economic strategy in which the fundamental matters centre on promoting smart sustainable growth facilitating inclusion. In this strategy, smart growth means emphasizing knowledge and innovation as the main premise directing and stimulating future growth. According to EU Regulation no. 1301/2013 of the European Parliament and of the EU Council dated 17 December 2013, a smart specialisation strategy means "national or regional innovation strategies which set priorities in order to build competitive advantage by developing and matching research and innovation's own strengths to business needs in order to address emerging opportunities and market developments in a coherent manner, while avoiding the duplication and fragmentation of efforts" [National/Regional Innovation...]. 
Atregional level Strategy Europe 2020 is realised through regional specialisations. In accordance with the EU directives, in the financial perspective 2014-2020 all regions should have their Regional Innovation Strategies for smart specialisation, RIS3. This will ensure that the means allocated for research and development will be spent effectively and beneficially for regional specialisations, at the same time making the realization of the Strategy Europe 2020 more effective. This is also important because every region has to have its own strategy in order to use EU funds.

Table 1. Similarities and differences in emphasis between Smart Specialisation Strategies and clusters

\begin{tabular}{|l|l|}
\hline \multicolumn{1}{|c|}{ Smart Specialisation Strategies } & \multicolumn{1}{|c|}{ Clusters } \\
\hline \multicolumn{2}{|c|}{ Similarities } \\
\hline Drivers of performance: productivity and innovation are critical for sustained growth \\
\hline \multicolumn{2}{|c|}{ Dultiple factors influence productivity and innovation } \\
\hline Importance of proximity and local spillovers and the critical role of locational context \\
\hline \multicolumn{2}{|c|}{ emphasis } \\
\hline Exploring emerging market opportunities & Critical mass \\
\hline $\begin{array}{l}\text { Facilitating knowledge spillovers between } \\
\text { knowledge domains }\end{array}$ & $\begin{array}{l}\text { External effects through shared infrastructure and } \\
\text { input markets }\end{array}$ \\
\hline $\begin{array}{l}\text { Exploit the related variety between knowledge } \\
\text { domains }\end{array}$ & Groups of companies in related industries \\
\hline $\begin{array}{l}\text { Drive structural change of an economy by } \\
\text { embedding innovative practices in the economy } \\
\text { and society }\end{array}$ & $\begin{array}{l}\text { Enhancing performance of a set of linked } \\
\text { companies }\end{array}$ \\
\hline
\end{tabular}

Source: [The Role of Clusters... 2013].

The concept of smart specialisation indicates the particular significance of cluster initiatives. Clusters should constitute a fundamental element in identifying priority areas and implementing the regional innovation strategy itself. Smart specialisation should use clusters in particular areas such as: access to research, education, and effective cluster management, which eventually will contribute to the strengthening and development of their potential for the realization of the strategy [Miłek]. With this reason in mind the European Commission recommends an approach aimed at using clusters to design and implement the RIS3. It is possible to point out both the similarities and differences in both concepts (see Table 1), but undoubtedly there is a strong relation between clusters and regional specialisation, which is continually expanded through the activities of the cluster entities.

\section{Lower Silesia - basic economic measures}

Lower Silesia is the seventh biggest region in Poland in terms of the size of its territory, and the sixth in terms of the population numbers. The region is an attractive 
place for investment for prospective foreign investors due to its human capital potential, its resources, geographical proximity to Germany and the Czech Republic, as well as the degree of development of its basic and technological infrastructure. The pace of development in Lower Silesia significantly exceeds the average economic development for the whole of Poland, which places it among the leaders in the country. GNP per capita in Lower Silesia is higher by over 5.2 thousand PLN than the national average. The region has also a high position in the country in terms of its expenditure on research and development, which shows its commitment to innovativeness. The selected indicators demonstrating the potential of the region of Lower Silesia in 2017 compared to Poland in general are presented in Table 2. According to the data presented in the table, Lower Silesia is seen as a strong part of the Polish economy, especially in GNP, work force and expenditure on investment and research and development.

Table 2. Selected macroeconomic indicators for Lower Silesia and for Poland in 2017 (in brackets: the placing of the region on a national scale)

\begin{tabular}{|c|c|c|}
\hline Indicator & Lower Silesia & Poland \\
\hline 1 & 2 & 3 \\
\hline \multicolumn{3}{|l|}{ Main economic indicators } \\
\hline Gross National Product in mln PLN (current prices) & $155816(3)$ & 1861112 \\
\hline GNP (in \%) & $8.4(4)$ & 100.0 \\
\hline GNP per capita (current prices) in PLN & $53659(2)$ & 48432 \\
\hline \multicolumn{3}{|l|}{ Geography and infrastructure } \\
\hline Total area in $\mathrm{km}^{2}$ & $19947(7)$ & 312679 \\
\hline Counties (powiaty) & 26 & 314 \\
\hline Boroughs (gminy) in total & 169 & 2478 \\
\hline Towns & $91(2)$ & 923 \\
\hline Rural localities & 2530 & 52512 \\
\hline \multicolumn{3}{|l|}{ Population and workforce } \\
\hline Population (in thousands) & $2902.5(6)$ & 38433.6 \\
\hline Percentage of urban population in the total population & $68.8(3)$ & 60.1 \\
\hline Workforce (in thousands) & $1135.5(6)$ & 15380.7 \\
\hline Average employment in industry (in thousands) & $232.5(5)$ & 2849.7 \\
\hline Average employment in building and construction (in thousands) & $41.8(6)$ & 614.1 \\
\hline Registered unemployed in general (in thousands) & $68.8(8)$ & 1081.7 \\
\hline Rate of registered unemployed (in \%) & $5.7(10)$ & 6.6 \\
\hline Average gross monthly pay in general (in PLN) & $4400.05(2)$ & 4283.73 \\
\hline $\begin{array}{l}\text { Average gross monthly pay in farming, forestry, hunting and fishery } \\
\text { (in PLN) }\end{array}$ & $4667.58(6)$ & 4597.51 \\
\hline
\end{tabular}


Table 2, cont.

\begin{tabular}{|c|c|c|}
\hline 1 & 2 & 3 \\
\hline $\begin{array}{l}\text { Average gross monthly pay in industry, building and construction } \\
\text { (in PLN) }\end{array}$ & $4718.40(2)$ & 4224.45 \\
\hline $\begin{array}{l}\text { Average gross monthly pay in: trade; vehicle repairs, transport and } \\
\text { warehousing; accommodation and catering; information and } \\
\text { communication (in PLN) }\end{array}$ & $3864.39(3)$ & 4019.26 \\
\hline $\begin{array}{l}\text { Average gross monthly pay in: financial services and insurance; } \\
\text { real estate services (in PLN) }\end{array}$ & $6167.96(2)$ & 6150.71 \\
\hline Average gross monthly pay in other services (in PLN) & $4200.19(4)$ & 4321.58 \\
\hline \multicolumn{3}{|l|}{ Expenditure on investment } \\
\hline Investment outlay (current prices) in million PLN & $304510.5(4)$ & 3831949.8 \\
\hline Investment outlay (current prices) per 1 resident in PLN & $104911(3)$ & 99703 \\
\hline \multicolumn{3}{|l|}{ Research and development } \\
\hline $\begin{array}{l}\text { Expenditure on research and development in total (current prices) } \\
\text { in mln PLN }\end{array}$ & $1517.8(6)$ & 20578.5 \\
\hline $\begin{array}{l}\text { Expenditure on research and development (current prices) } \\
\text { per } 1 \text { resident in PLN }\end{array}$ & $532(4)$ & 536 \\
\hline University students per 10 thousand of the population & $404.2(3)$ & 317.1 \\
\hline University graduates per 10 thousand of the population & $116.1(3)$ & 97.5 \\
\hline
\end{tabular}

Source: own elaboration based on data in [Rocznik Statystyczny Województw 2018].

\section{Sectoral specialisation in Lower Silesia}

According to the Regional Innovation Scoreboard 2019, the Region of Lower Silesia (PL51) is a Moderate-Innovator and innovation performance has increased over time (4.8\%) [Regional Innovation Scoreboard 2019]. Table 3 shows the normalised scores per indicator and the relative results of the region compared to the rest of Poland and the EU, and the Regional Innovation Index (RII) in 2019 compared to that of Poland and the EU in 2019, the RII in 2019 compared to that of the EU in 2011, and the performance change over time between 2011 and 2019.

The areas of smart specialisations in Lower Silesia, in accordance with the annex to the Regional Innovation Strategy for the Dolnośląskie Region 2011-2020, entitled "The strategic framework for smart specialisations of Lower Silesia", are as follows:

1. Chemical and pharmaceutical industry.

2. Spatial mobility.

3. High quality food.

4. Natural resources and recyclable materials.

5. Machine and equipment manufacturing, materials-processing technology.

6. Information and communication technologies (ICT). 
Table 3. Main factors for the Lower Silesia region according to the Regional Innovation Scoreboard 2019

\begin{tabular}{|l|r|r|r|r|}
\hline \multirow{2}{*}{ Factor } & \multirow{2}{*}{ Data } & \multirow{2}{*}{$\begin{array}{c}\text { Normalised } \\
\text { Score }\end{array}$} & \multicolumn{2}{c|}{ Relative to } \\
\cline { 4 - 5 } & & & PL & EU \\
\hline Tertiary education & 46.4 & 0.576 & 102 & 125 \\
\hline Lifelong learning & 3.3 & 0.082 & 79 & 26 \\
\hline International scientific co-publications & 413 & 0.362 & 112 & 63 \\
\hline Most-cited scientific publications & 0.053 & 0.256 & 108 & 47 \\
\hline R\&D expenditures public sector & 0.23 & 0.297 & 82 & 52 \\
\hline R\&D expenditures business sector & 0.46 & 0.328 & 84 & 56 \\
\hline Non-R\&D innovation expenditures & \pm & 0.606 & \pm & \pm \\
\hline Product/process innovations & \pm & 0.161 & \pm & \pm \\
\hline Marketing/org. innovations & \pm & 0.108 & \pm & \pm \\
\hline SMEs innovating in-house & \pm & 0.159 & \pm & \pm \\
\hline Innovative SMEs collaborating & \pm & 0.120 & \pm & \pm \\
\hline Public-private co-publications & 8.9 & 0.190 & 129 & 47 \\
\hline PCT patent applications & 1.68 & 0.138 & 111 & 32 \\
\hline Trademark applications & 3.05 & 0.211 & 63 & 48 \\
\hline Design applications & 4.63 & 0.505 & 92 & 103 \\
\hline Employment MHT manuf.KIS services & 19.1 & 0.656 & 161 & 131 \\
\hline Sales new-to-market/firm innovations & \pm & 0.305 & \pm & \pm \\
\hline Average score & -- & 0.298 & -- & -- \\
\hline Country EIS-RIS correction factor & -- & 0.930 & -- & -- \\
\hline Regional Innovation Index 2019 & -- & 0.277 & -- & -- \\
\hline RII 2019 (same year) & -- & -- & 101.6 & 57.0 \\
\hline RII 2019 (cf. to EU 2011) & -- & -- & -- & 59.7 \\
\hline Regional Innovation Index 2011 & & - & -- & -- \\
\hline RII 2011 (same year) & - & 103.1 & 54.9 \\
\hline RII - change between 2011 and 2019 & & - & -- \\
\hline
\end{tabular}

\pm Relative-to-EU scores are not shown as these would allow recalculating confidential regional CIS data.

Source: [Regional Innovation Scoreboard 2019].

According to the European Observatory for Clusters and the Industrial Change Mapping Tool, in 2016 (for the latest available data see Figure 1) the highest specialisation in the region can be observed in video production and distribution (3.54 indicator value), non-metal mining (3.27 indicator value) and furniture production (3.02 indicator value). In further positions there are production of leather goods, and lighting and electrical equipment. The most specialist sectors according 




Figure 1. Lower Silesia Profile by Sector for Specialization 2016

Source: [https://interactivetool.eu/EASME/EOCIC/EOCIC_2.html].

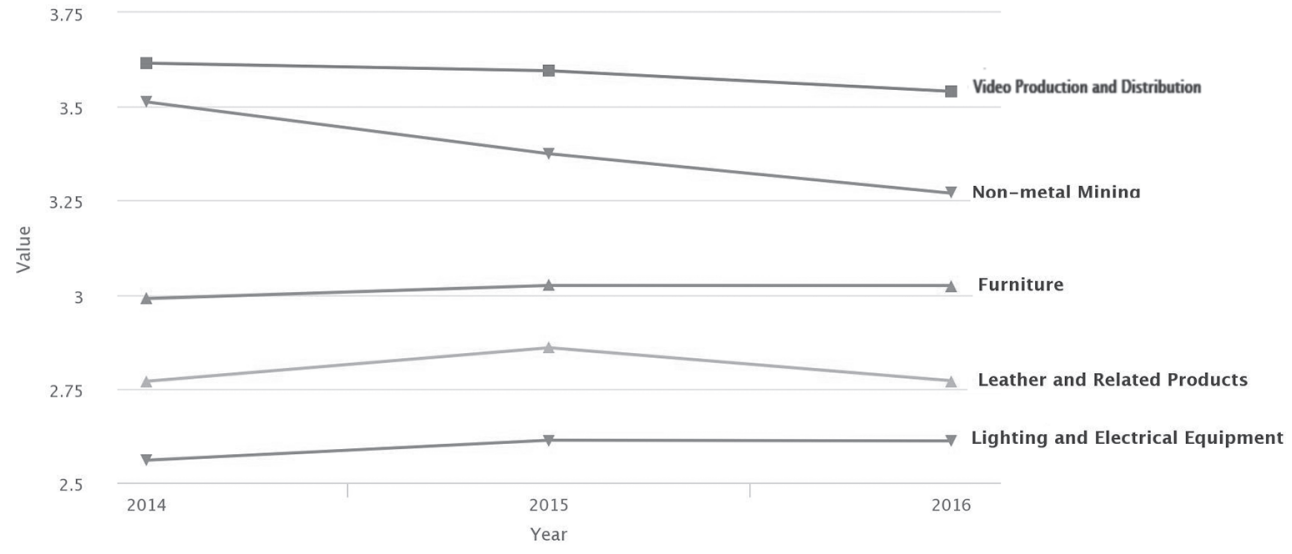

Figure 2. Evolution of Lower Silesia Region's performance between 2014 and 2016

Source: [https://interactivetool.eu/EASME/EOCIC/EOCIC_2.html]. 
to the presented data do not correspond with the Strategic Framework and the priority sectors indicated in that document.

The dynamics of changes in the indicator of specialisation for the five leading sectors in the studied region are presented in Figure 2. It should be noted that between 2014 and 2016 the value of specialisation in three of the sectors decreased (video production and distribution, non-metal mining, and leather and related products), while in furniture production, and lighting and electrical equipment it levelled off [The Evolution...].

\section{Clusters and regional specialisation in the region of Lower Silesia}

The first clusters emerged in the economy many decades ago and since then entrepreneurs have noted more advantages than threats resulting from functioning in such a group of companies. The positive aspects of enterprises gathering into clusters can be seen in almost every department, starting from research and development, marketing, sales, production, personnel, to procurement. Clusters, apart from their influence on the companies involved, also have an impact on the region in which they operate. The created clusters, especially bunches of advanced technologies, attract to the region a qualified workforce, increasingly more specialised, and also bring changes in the institutions collaborating with the clusters. Universities quite often adapt their curricula to the requirements of enterprises involved in clusters. Therefore clusters are perceived as a source of regional specialisation because along with the development of those entities, there follows a greater concentration of a particular type of production or services provided in the region.

Depending on the analysed source of information, in Lower Silesia there operate from five to as many as fifteen clusters, a fact which is connected with the difficulty of defining this concept and the creation of pseudo-cluster initiatives due to the possibility of obtaining financial support offered as part of the conducted pro-cluster policy. Some of the clusters in Lower Silesia are dormant or have suspended their activity. According to the European Cluster Collaboration Platform [The European Cluster Collaboration Platform], which is the basis of European clusters, there are five clusters located in this region as shown in Table 4. Three out of the five Lower Silesian clusters have been awarded the Bronze Label of the European Cluster Excellence Initiative (ECEI), which is given to cluster management organizations that are benchmarked, and demonstrate their interest in striving for excellence. However none of the clusters in this region have been included in the European Strategic Cluster Partnerships for Going International (ESCP-4i) aimed at collaborating on strategies to go international jointly, and help European SMEs access third markets.

The development of clusters in Lower Silesia mostly takes place through their financing from EU funds, as well as funds provided by the local authorities and at 
Table 4. List of Cluster Organisations in the Lower Silesia Region according to the European Cluster Collaboration Platform

\begin{tabular}{|c|c|c|c|}
\hline Name & Sector(s) & $\begin{array}{c}\text { Cluster Excellence } \\
\text { Label }\end{array}$ & $\begin{array}{c}\text { ESCP-4i } \\
\text { Membership }\end{array}$ \\
\hline $\begin{array}{l}\text { Centre for Energy } \\
\text { Technologies Cluster } \\
\text { - Free Enterprise } \\
\text { Association }\end{array}$ & $\begin{array}{l}\text { Construction Products and Services, } \\
\text { Education and Knowledge Creation } \\
\text { Environmental Industries } \\
\text { Photovoltaics, Solar/Thermal energy } \\
\text { Specialised construction activities, } \\
\text { Power generation / renewable sources }\end{array}$ & Bronze Label & - \\
\hline $\begin{array}{l}\text { Cluster of Innovative } \\
\text { Manufacturing } \\
\text { Technologies } \\
\text { Association } \\
\text { CINNOMATECH }\end{array}$ & $\begin{array}{l}\text { Information Technology and Analytical } \\
\text { Instruments, Metalworking Technology } \\
\text { Digital Industries, Mobility } \\
\text { Technologies } \\
\text { Knowledge Management, Process } \\
\text { Management, Machine Tools } \\
\text { Specialised construction activities, } \\
\text { Advanced manufacturing systems }\end{array}$ & - & - \\
\hline $\begin{array}{l}\text { The Research and } \\
\text { Development and } \\
\text { Innovation Cluster }\end{array}$ & $\begin{array}{l}\text { Business Services, Education and } \\
\text { Knowledge Creation } \\
\text { Creative services, Socio-economic } \\
\text { models, economic aspects } \\
\text { New or improved organisational } \\
\text { models, New or improved service } \\
\text { processes }\end{array}$ & - & - \\
\hline $\begin{array}{l}\text { The Innovative } \\
\text { Medicine Cluster }\end{array}$ & $\begin{array}{l}\text { Business Services, Education and } \\
\text { Knowledge Creation } \\
\text { Digital Industries, Medical Devices } \\
\text { Creative services, Education and } \\
\text { Training } \\
\text { e-Health (e.g. healthy ageing)Human } \\
\text { health activities (medical services) }\end{array}$ & Bronze Label & - \\
\hline $\begin{array}{l}\text { NUTRIBIOMED } \\
\text { Cluster }\end{array}$ & $\begin{array}{l}\text { Biopharmaceuticals, Business Services } \\
\text { Advanced Packaging, } \\
\text { Biopharmaceuticals } \\
\text { Food Additives/Ingredients/Functional } \\
\text { Food, Food Technology } \\
\text { Basic pharmaceutical products \& } \\
\text { pharmaceutical preparations, Food, } \\
\text { beverage \& tobacco products }\end{array}$ & $\begin{array}{l}\text { Bronze Label } \\
\text { Other: 2x Polish } \\
\text { Agency for } \\
\text { Enterprise } \\
\text { Development } \\
\text { award and } \\
\text { NUTRIBIOMED } \\
\text { cluster coordinator } \\
\text { accreditation by } \\
\text { Ministry of } \\
\text { Economic } \\
\text { Development }\end{array}$ & - \\
\hline
\end{tabular}

Source: [The European Cluster Collaboration Platform]. 
national level. In accordance with the adopted innovation strategy for this region, one of the strategic objectives is the strengthening of the regional blocks of competences i.e. supporting regional clusters. The strategy underlines the significant role played by clusters in regional development, and indicates strategic industrial clusters (linked to copper mining and the production of energy) and service clusters (linked to healthcare and tourism) generating a large number of jobs, which finds a positive reflection in the region's economic results. The region also provides conditions creating new clusters, especially in the field of modern and original technologies. The policy of the local authorities in Lower Silesia is directed at the creation and support for clusters, seeing them as an opportunity to raise the level of specialisation and regional competitiveness. The support for cluster initiatives, the attractiveness of Lower Silesia for investors and the region's potential, cause the newly formed clusters to focus on companies involved in IT and advanced technologies, which in turn leads to a growing regional specialization regarding innovativeness and new technologies in comparison to the other regions in Poland.

Clusters in Lower Silesia are mostly young, where the involved companies are just beginning to create their networks of relations. Undoubtedly many potential sectors and localisations for new clusters exist locally, such as the production of furniture. Currently in the region there operate several large furniture manufacturers such as "Gawin" and "Bodzio", as well as numerous smaller producers, e.g. in the area of Twardogóra, and creating a cluster seems to be a natural process for this sector. Another sector offering good conditions for creating clusters is spa and wellness services, because Lower Silesia is a home for many spa localities (e.g. Duszniki-Zdrój) which, when combined with tourist facilities, could become a cluster. This is also the case of localities offering the infrastructure for winter sports (e.g. Karpacz), where the existing companies, hotels and restaurants together can form a winter sports cluster. Potentially it may also be possible to create a cluster of financial and accounting services, and an IT services cluster, because numerous companies establish specialist units of transnational corporations precisely in Wrocław. This type of centre has been founded by, for example, HP and IBM, which may be the first step to the creation of an innovation cluster in the studied region. It is worth noting that in the region of Lower Silesia there are as many as three clusters involved in energy production, which seems unwarranted. Those clusters should be consolidated, especially since all of them are in the initial stages of development and that by operating separately they will be unable to reach a position higher than their competitors. It could be thought that the combination of all their potentials will allow to create a powerful energy production cluster with great prospects for future development.

The impact of clusters on Lower Silesia's specialisation can manifest itself through the following:

- Developing extended production networks comprised of specialist sub-suppliers and collaborators, and building a market of specialist production factors - an 
example of such activities can be the automotive sector and the sector of electrodomestic appliances in which a network constituting a comprehensive production chain is being created.

- Creating new business entities in the region, developing entrepreneurship and involving local small and medium enterprises in the cluster structures, which translates into their greater specialisation and effectiveness of functioning - the activity of most clusters in Lower Silesia is linked with setting up new companies and research units in the region. The automotive cluster, Ceramika Bolesławiecka and the electro-domestic appliances cluster can serve as examples.

- Creating a culture of innovation and stimulating the flow of knowledge and learning processes, generating innovation, and - owing to the geographic closeness of the entities and interaction between them - creating academic units such as the Wrocław Research Centre EIT + Sp. z o.o., which supports the work of the Community of Science and Innovation cluster, as well as many other institutions cooperating with Lower Silesian clusters.

- Increasing the attractiveness of a given locality in order to attract direct foreign investment - together with the influx of important foreign business investors into the region, e.g. Toyota and LG, also some smaller companies, usually the subcontractors for the dominant businesses.

- Creating an attractive jobs market which brings in qualified personnel, and high quality of human capital - Lower Silesian clusters are not yet a permanent fixture in the regional climate, but one can assume that together with their development the process of identifying the region with a certain type of production and services will also take place. Currently the region is known for its ceramic production which is not as yet identified with a particular cluster.

- Developing a science infrastructure and a greater degree of the use of science on the part of businesses - both the NutriBioMed cluster and SIDE Cluster place in the centre of their attention the development of interaction between science and the economy, which is reflected in the simultaneous growth of the effectiveness of the academic research and the production and service companies which take advantage of that knowledge.

\section{Conclusion}

Smart specialisation means the ability to determine the unique resources of a country and/or region, and then bearing in mind the existing conditions, to build competitive advantage with the participation of a wide range of stakeholders in order to attain in future the optimum level of development.

Lower Silesia is one of the most dynamically developing regions in Poland, in which the economic indicators reach values significantly higher than the national average. This results in a steady inflow of qualified personnel, foreign capital and 
technologies which in turn creates excellent opportunities for the development of both small and medium local enterprises as well as the entire region. In the case of Lower Silesia, setting up new enterprises is often linked with expanding the stream of direct foreign investment, and the creation or development of clusters. Every instance of increased activity of clusters creates new jobs which has a positive impact on unemployment and the structure of employment. Cluster participants continuously improve their competitiveness and effectiveness of operations, and contribute to a further specialization in the studied region. Nowadays in Lower Silesia there operate some key clusters which function effectively in the region but at the same time meet the European norms regarding cluster organisations. Hence it can be stated that they will become a driving force in the local economy, and will also extend the local specialisation.

\section{References}

Evolution of Dolnoślaskie Region's performance between 2014 and 2016, https://interactivetool.eu/ EASME/EOCIC/EOCIC_2.html (13.07.2019).

Foray D., David P.A., Hall B.H., 2011, Smart Specialization. From Academic Idea to Political Instrument, the Surprising Career of a Concept and the Difficulties Involved in its Implementation, MTEI Working Paper 2011-01, Ecole Politechnique Federale de Lausanne, Lausanne.

Foray D., Goddard J., Beldarrain X.G. et al., 2012, Guide to Research and Innovation Strategies for Smart Specialisation (RIS 3), European Commission.

https://interactivetool.eu/EASME/EOCIC/EOCIC 2.html (13.07.2019).

Miłek D., Specjalizacje regionalne a Strategia Europa 2020, http://zif.wzr.p1/pim/2013_1_2_13.pdf (21.07.2019).

National/Regional Innovation Strategies for Smart Specialisation (RIS3), The European Commission, https://ec.europa.eu/regional_policy/sources/docgener/informat/2014/smart_specialisation_en. $\operatorname{pdf}(24.07 .2019)$.

Nazarko Ł., 2014, Inteligentne specjalizacje polskich regionów - przyczynek do ewaluacji, Przedsiębiorczość i Zarządzanie, t. XV, z. 8, cz. I, pp. 247-262.

Ochojski A., Polko A., Churski P., Kopczewska K., 2016, Specjalizacja regionalna: podstawy koncepcyjne i aspekty interpretacyjne, Studia KPZK, no. 170.

Regional Innovation Scoreboard, 2019, Poland, https:/ec.europa.eu/docsroom/documents/35935 (24.07.2019).

Rocznik Statystyczny Województw, 2018, Główny Urząd Statystyczny, Zakład Wydawnictw Statystycznych, Warszawa 2018.

Strategie innowacji krajowych/regionalnych na rzecz inteligentnej specjalizacji (RIS 3), 2014, Komisja Europejska, http://ec.europa.eu/regional_policy/sources/docgener/informat/2014/smart_specialisation_pl.pdf (23.07.2019).

The Evolution of the Performance of the Dolnosilaskie Region between 2014 and 2016, https://interactivetool.eu/EASME/EOCIC/EOCIC_2.html (13.07.2019).

The European Cluster Collaboration Platform, https://www.clustercollaboration.eu/cluster-list?combine $=\&$ region_code $=$ PL51 (23.07.2019).

The Role of Clusters in a Smart Specialization Strategy, 2013, The European Commission, https:// ec.europa.eu/research/evaluations/pdf/archive/other_reports_studies_and_documents/clusters smart_spec2013.pdf (24.07.2019). 